\title{
Contribution Analysis Following Student Organization Activities on Improving Learning Commitment of Unimed Students
}

\author{
Jongga Manullang \\ Electrical Education Department, FT \\ Universitas Negeri Medan \\ Medan, Indonesia \\ mjongga@yahoo.com
}

\author{
Dilinar Adlin \\ Dance Education Department, FBS \\ Universitas Negeri Medan \\ Medan, Indonesia \\ dilinaradlin@gmail.com
}

\author{
Hariadi \\ Physical Education and Recreation, FIK \\ Universitas Negeri Medan \\ Medan, Indonesia \\ hariadiumar@gmail.com
}

\begin{abstract}
This study examines the problem (1) How is Unimed Student Learning commitment, and (2) Contribution analysis follows the activities of student organizations towards Unimed Student Learning Commitments.This research was carried out in Unimed for all students of 2017/2018 academic year who had been registered as members of the student organization in Unimed, and the research sample was determined by total sampling technique. This research data was collected using a questionnaire instrument with a Likert scale pattern. The results of this study will be processed using descriptive correlational techniques, by testing the normality and homogeneity of variables, test the requirements of analysis, and test hypotheses using the $t$ test. The findings of this study are expected to give a signal that following the activities of student organizations has significant benefits for the formation of student learning commitments so that they can develop appropriate learning motivation in achieving maximum success in their lecture activities.
\end{abstract}

Keywords: Contributions, Student Organizations, Learning Commitments

\section{INTRODUCTION}

Students are national assets and strategic human resources so they need to be given the widest possible opportunities and opportunities to actualize themselves fully and responsibly. As an academic community in the framework of developing science, technology and art and at the same time is a lecturer partner in the dialogical teaching and learning process. Whereas in the process of self-development of students, student advisers always show an attitude of hand and little interference. Likewise, in arranging student organizations in universities, they always adhere to the principle "from, by and for students"

In general, policies in various universities currently reflect a relatively similar situation, namely the lack of integration between curricular activities and extracurricular activities. This condition is clearly not conducive to encourage student involvement in extracurricular activities that aim to develop the potential and self-actualization of students.

1. Quantitatively, very few students are interested in reasoning and scientific development programs; talents, interests, and abilities; welfare; social care; and supporting activities. This situation was motivated by, among other things, the high cost of tuition which resulted in them wanting to finish quickly and immediately find work to earn income.

2. Students who participate in student organizations (Ormawa) intra tertiary institutions are relatively small in number, but when events occur that concern the interests of the wider community, students quickly show their attitude through protests that tend to be reactive and sporadic. The involvement of students in this kind of activity, on the one hand is positive because they show a high level of sensitivity and social care. But on the other hand it is negative because expressing protest tends to ignore academic rules that are upheld in universities.

3. The involvement of college extra organizations directly on campus will have an impact on the division of students, which in turn can lead to division and conflict among students. Such involvement is clearly contrary to the Higher Education and the Director General of Higher Education Decree Number 26 / Dikti / Kep / 2002, concerning the Prohibition of Extra Campus or Political Party Organizations in Campus Life.

4. This kind of misunderstanding has an impact on the attitude of students who feel entitled to ignore the authority of the university leadership to organize Ormawa on campus. This misunderstanding needs to be addressed 
immediately through various activities facilitated by the university leadership.

The learning commitment that is meant is the determination or promise of students to themselves to do all the learning activities that have been determined by the institution that organizes the study program in the college.

Lecture activities that must be carried out by students have been designed in such a way by educational institutions ranging from the central level (college), faculty level, study program level, to the level of lecturer lecturers. Based on scientific studies conducted at the tertiary level, the courses that students must follow have been grouped in such a way that there are groups of courses (1) higher education level which are subjects that are required for all students of a university, $(2$ ) faculty level, which is a course that is required for all students at the faculty level in a university, and (3) the level of department / study program, which is a subject that is required only for students in a particular department / study program.

Lecture activities on each type of course specified, through a policy set by the university leadership, namely the Unimed Chancellor, were determined through Decree No. 065 / UN33 / Kep / 2016 which formulated 6 main activities of lectures that must be carried out by Unimed students, namely (a) routine assignments, (b) book review reports, (c) review of report journals, (d) engineering ideas, (e) mini research, and (f) projects.

The extent to which involvement in the activities of student organizations influences students' learning commitment in preparing to become prospective educators and / or education staff needs to be studied scientifically through scientific research entitled "Contribution Analysis Following Student Organization Activities on Unimed Student Learning Commitments"

Based on the background of the problems raised above, the problem of this research can be formulated as follows:

1. How is the student's learning commitment in preparing to become a prospective educator and / or educational staff in Unimed?

2. How do you contribute to the activities of student organizations towards the learning commitment of Unimed students?

\section{LITERATURE REVIEW}

\section{The Nature of Student Learning Commitments}

Learning commitment describes a situation in which students express their determination or motivation to carry out learning activities earnestly so that they can prepare themselves in such a way as to achieve the ultimate goal of their learning activities. This is in accordance with the concept of organizational commitment proposed by Robbin (2006: 94 95) which states that organizational commitment shows the involvement of members in the organization which describes the willingness of members to side with certain work that has been determined. This means that with the commitment to learning, students are willing and able to link themselves to the learning activities that must be done seriously. In a Doctoral
Program Student writing on the "Learning Commitment / My Ph.D Life" page, Chrisphdlife with the title "we need more commitment than motivation" (https://chrisphdlife.wordpress.com/tag/komitmen-belajar/) revealed that "commitment comes from within ourselves about how much consistency we do what is planned. Commitment is not based on feelings (like it or not, enthusiasm, or not).

Prayitno (2009: 171) which states that commitment is the willpower, determination, and determination, to do better, to no longer repeat the wrong actions or violate it; will not do the same thing in the same place or elsewhere. Luthans (2006: 249) explains that organizational commitment can be defined as (1) a strong desire to remain as a member of a particular organization, (2) a desire to strive according to the wishes of the organization, and 3) certain beliefs, and acceptance of organizational values and goals, then it can be synthesized that student learning commitment is as (1) a strong desire to remain as a student in a chosen study program, (2) a desire to strive according to the study program's wishes, and 3) certain beliefs, and acceptance of the study program's grades and objectives.

Characteristics or characteristics of student learning commitment can be described by analyzing Porter's opinion in Mowday (2009: 07) regarding organizational commitment which is characterized by three things, namely: (1) acceptance of organizational values and goals; (2) readiness and willingness to make serious efforts on behalf of the organization; (3) loyalty, which is the desire to remain a member of the organization.

Based on the opinions of the experts above, it can be concluded that student learning commitment can be described as a determination or intention of students to carry out all the tasks that are their responsibility in preparing themselves later as prospective educators and / or educational staff who are professionals in the field of education.

\section{The Nature of Student Organizations}

According to Joesoef (1978: 23) student organizations are a container that is expected to be able to accommodate all student activities and is also a means to improve thinking or reasoning skills regularly outside formal lectures, organizational skills, and fostering leadership. Meanwhile according to Launa (2000: 32), campus student organizations are an organization or organization engaged in student affairs, which is equipped with clear and planned technical tools such as structures, mechanisms, functions, procedures, work programs, and other elements. which serves to direct all the potential that exists in the organization to the goals or the ultimate goals to be achieved.

It can be concluded that student organizations are a vehicle or means of self-development of students towards personality integrity, expansion of insight, improvement of scholarship, as well as improving leadership, reasoning, favorite interests, and students' welfare in student life in higher education, which in practice is equipped with clear and planned, such as structure, mechanism, function, procedure, work program, and other elements that function to direct all the potential that exists in 
the organization to the final goals or ideals that it wants to achieve.

According to Priambodo and Sarwono (in the journal Leny and P. Tommy Y. Suyasa, 2006), there are several characteristics inherent in students who are active in student organizations.

1. Happy to spend time with various student activities. Students who are active in student organizations almost always want to be involved in the daily management and committee of various activities and events held by the organization. Dealing is willing to be actively involved in encouraging the implementation of various activities in the organization where he joins.

2. Tend to sit and chat frequently in the student organization's room or office that was followed. Students who are active in student organizations tend to take more time to gather in a room or office while sitting and talking with other members of the organization regarding matters related to the organization that are being followed and on issues that are circulating. in the outside environment or society.

3. Tend to have broad insight about the development of the outside world as well as about things that happen around campus. In addition to having broad insight, students who are active in student organizations also tend to look at things critical.

\section{THINKING FRAMEWORK}

Students' learning commitment to make themselves later as educators and / or education personnel are encouraged or determined by many factors both from themselves and from outside themselves. If the external factors are the chosen institution / study program in the form of providing various types and levels of lecture activities as outlined in the curriculum, syllabus, RPP that must be done by students, then the perception factor from within students will determine how to react and implement all types and levels activities programmed by the study program.

Student organization is a vehicle or means of selfdevelopment of students towards personality integrity, expansion of insight, improvement of scholarship, and enhancement of student leadership, reasoning, interest, and well-being in student life in higher education, which in its implementation is equipped with clear and planned technical tools. such as structures, mechanisms, functions, procedures, work programs, and other elements that function to direct all the potential that exists in the organization to the ultimate goals or ideals that it wants to achieve.

Students are young people who have a big role in determining the direction of improvement of this nation. By being aware of these responsibilities, students are expected to be able to develop abilities and skills not only from lecturing activities but from various types of activities on campus, one of which is a member of a student organization.Based on the mindset above it can be synthesized that following the activities of student organizations has a positive relationship with student commitment in Unimed, with the research paradigm as follows:

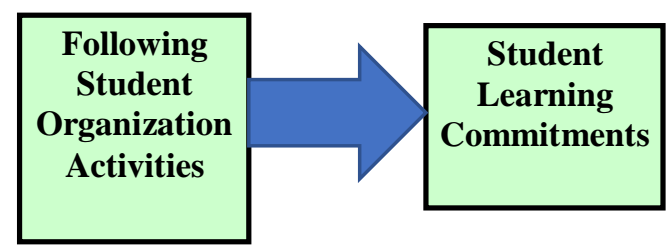

Fig 1. Contributions Following Student Organization Activities on Student Learning Commitments

\section{Conclusions}

Based on the theoretical framework and thinking framework above, it can be concluded "There is a contribution that means following the activities of student organizations towards the commitment of student learning in Unimed".

\section{REFERENCES}

[1] Echols, John M., 2003. Kamus Inggris Indonesia. Jakarta: Gramedia

[2] Luthans, Fred, 2006. Perilaku Organisasi; Edisi Kesepuluh; Penerjemah: Vivin Andhika Yuwono, dkk.

[3] Mowday, 1982. http://jurnal-sdm. blogspot.com/2009/07/komitmenkaryawan-definisi-dan-jenis.html.

[4] Peraturan Menteri Tenaga Kerja dan Transmigrasi No. Per.22/Men/IX/2009 tentang Penyelenggaraan Pemagangan di Dalam Negeri.

[5] Prayitno, 2009. Dasar Teori dan Praksis Pendidikan. Jakarta: Gramedia.

[6] Rakhmat, Jalaluddin, 2005. Psikologi Komunikasi. Edisi Revisi. Bandung: Remaja Rosdakarya.

[7] Robbins, Stephen P.,2006. Perilaku Organisasi. Edisi Kesepuluh. Alih Bahasa Drs. Benyamin Molan. Jakarta: kelompok Gramedia.

[8] Wau, Yasaratodo, Anifah, Fauzi Kurniawan, 2017. Persepsi Tentang Hasil Refleksi Penyelenggaraan Kegiatan Magang 1 dan Hubungannya dengan Komitmen Mahasiswa Membekali Diri Menjadi Calon Tenaga Pendidikan di Program Studi Pendidikan Luar Sekolah FIP Unimed.

[9] http://id.shvoong.com/social-sciences/psychology/1837978-definisipersepsi 